\title{
Public Health and the COVID-19 Pandemic
}

\author{
Guest Editors \\ António Sousa-Uva, Lisbon \\ Helena Canhão, Lisbon \\ Paulo Sousa, Lisbon \\ Rui Santana, Lisbon
}

17 figures, 12 in color, and 14 tables, 2021 


\section{Disclosure Statement}

Publication of this PHPH 2020 supplement issue entitled "Public Health and the COVID-19 Pandemic" was financially supported by National Funds through FCT - Fundação para a Ciência e Tecnologia (the Portuguese national funding agency for science, research, and technology - https://www.fct.pt/) within the scope of Special support for rapid implementation projects for innovative response solutions to COVID-19 pandemic, and Special support for research projects on the impact of health emergency caused by COVID-19 on gender inequalities and violence against women and domestic violence with the references: 053, 099, 136, 608; 062 |Gender Research. Besides the official sponsorship of FCT, the Guest Editors have no further disclosures.

\section{FCT}

S. Karger

Medical and Scientific Publishers Basel $\cdot$ Freiburg $\cdot$ Hartford $\cdot$ Oxford Bangkok · Dubai · Kuala Lumpur . Melbourne $\cdot$ Mexico City Moscow $\cdot$ New Delhi $\cdot$ Paris · Shanghai $\cdot$ Tokyo

\section{Disclaimer}

The statements, opinions and data contained in this publication are solely those of the individual authors and contributors and not of the publisher and the editor(s). The appearance of advertisements in the journal is not a warranty, endorsement, or approval of the products or services advertised or of their effectiveness, quality or safety. The publisher and the editor(s) disclaim responsibility for any injury to persons or property resulting from any ideas, methods, instructions or products referred to in the content or advertisements.

Drug Dosage

The authors and the publisher have exerted every effort to ensure that drug selection and dosage set forth in this text are in accord with current recommendations and practice at the time of publication. However, in view of ongoing research, changes in government regulations, and the constant flow of information relating to drug therapy and drug reactions, the reader is urged to check the package insert for each drug for any change in indications and dosage and for added warnings and precautions. This is particularly important when the recommended agent is a new and/or infrequently employed drug.
All rights reserved.

No part of this publication may be translated into other languages, reproduced or utilized in any form or by any means, electronic or mechanical, including photocopying, recording microcopying, or by any information storage and retrieval system, without permission in writing from the publisher or, in the case of photocopying, direct payment of a specified fee to the Copyright Clearance Center (see 'General Information').

(C) Copyright 2021 NOVA National School of Public Health Published by S. Karger AG, Basel

P.O. Box, CH-4009 Basel (Switzerland) e-ISBN 978-3-318-06939-6 


\section{Contents}

Editorial

1 The Role of Schools of Public Health in the COVID-19 Pandemic Middleton, J. (Brussels)

Brief Reports

4 COVID-19 Transmission Dynamics: A Space-and-Time Approach Moniz, M.; Soares, P.; Nunes, C. (Lisbon)

11 Inpatient Hospitalizations during the First Wave of COVID-19 in Portugal Rocha, J.; Soares, P.; Filipe, C.; Lopes, S.; Teixeira, M.; Fonseca, I.; Sousa, J.; Marquês, D.; Mestre, R.; Duarte, A.; Santana, R. (Lisbon)

18 COMPRIME - COnhecer Mais PaRa Intervir MElhor: Preliminary Mapping of Municipal Level Determinants of COVID-19 Transmission in Portugal at Different Moments of the 1st Epidemic Wave

Sousa, P.; da Costa, N.M.; da Costa, E.M.; Rocha, J.; Ricoca Peixoto, V.;

Campos Fernandes, A.; Gaspar, R. (Lisbon); Duarte-Ramos, F. (Porto); Abrantes, P.; Leite, A. (Lisbon)

26 The COVID-19 Impact in Hospital Healthcare Workers: Development of an Occupational Health Risk Management Program

Mendonça-Galaio, L.; Sacadura-Leite, E.; Raposo, J.; França, D.; Correia, A.; Lobo, R.; Soares, J.; Almeida, C.; Shapovalova, O.; Serranheira, F.; Sousa-Uva, A. (Lisbon)

32 Domestic Violence during the COVID-19 Pandemic in Portugal Gama, A.; Pedro, A.R.; de Carvalho, M.J.L. (Lisbon); Guerreiro, A.E. (Maia/Porto); Duarte, V. (Lisbon/Maia); Quintas, J. (Porto); Matias, A. (Almada); Keygnaert, I. (Porto); Dias, S. (Lisbon)

41 Erratum

42 COVID-19 Barometer: Social Opinion - What Do the Portuguese Think in This Time of COVID-19?

Pedro, A.R.; Gama, A.; Soares, P.; Moniz, M.; Laires, P.A.; Dias, S. (Lisbon)

51 Excess Non-COVID-19 Mortality in Portugal: Seven Months after the First Death

Vieira, A.; Ricoca Peixoto, V.; Aguiar, P.; Sousa, P.; Abrantes, A. (Lisbon)

\section{Author and Subject Index}

(C) 2021 The Author(s.) Published by S. Karger AG, Basel on behalf of Escola Nacional de Saúde Pública

This is an Open Access article licensed under the Creative Commons Attribution-NonCommercial-4.0 International License (CC BY-NC) (http://www.karger.com/Services/OpenAccessLicense), applicable to the online version of the article only. Usage and distribution for commercial purposes requires written permission. 